\title{
Hispania, Italia and Occitania: Latin and the Vernaculars, Bilingualism or Multilingualism?
}

\author{
Arie Schippers
}

\section{Romance Vernaculars}

From medieval times in Italy, the Romance vernaculars and their literatures stood opposite Latin, which was the official, Church and literary language. Dante Alighieri's Latin work De vulgari eloquentia is a testimony to this linguistic situation. The work describes the situation in Italy and is to a large extent the justification of the place that Dante's poetry school occupied in the overall picture. But the situation in Italy - the cradle of Latin - does not stand in isolation from the rest of southern Europe, such as Hispania (Arabic al-Andalus and the region of present-day Spain and Portugal) and their respective literatures, and Occitania, the region where the oldest vernacular lyric of medieval Europe manifested itself, mainly in the love poetry of the troubadours.

\section{Occitan}

The linguistic space of Occitania was originally around Toulouse, in the Languedoc, in Provence and in Aquitania, the region that today we call the Midi. Occitania is a relatively new name for the region where Occitan was spoken. The name is derived from the word oc (Latin hoc), which means 'yes'. The earlier terms Provence, Provençal, or Languedoc or Aquitania were not sufficient to denote the linguistic region. Today, however, the language from the north of France called langue d'oül (Latin hoc illud / hoc ille) dominates the whole area that we call the Midi or southern France. There are some specific language pockets where Occitan dialects are still spoken, for example in the Aran valley in Spain, where the Aranese Occitan dialect is an officially recognized language. ${ }^{1}$ Moreover, there is a certain artificial revival of forms of

1 In Val d'Aran teaching at elementary schools starts with three years of Aranes. In his seventh year the pupil also learns the other two official languages of Spain, Catalan and Castilian. So here we find a multilingual educational system. 
written standard Occitan language in the Occitan region of France: many bulletins on and announcements of cultural events appear on the internet in Occitan. Catalan, Valencian and Occitan are kindred languages, perhaps variants of one and the same language and culture.

After his victory over the Almohads at las Navas de Tolosa in $1212,{ }^{2}$ Peter II of Aragon dreamt of having a kingdom that would span the Pyrenees and comprise the Occitan and Catalan regions. Later that year, however, he perished during the battle of Muret. ${ }^{3}$ Occitan thus failed to become a 'national' language.

Culturally speaking, Occitan was exceedingly diffuse, not least owing to the love poetry of the troubadours, ${ }^{4}$ although much of their poetry was devoted to political subjects, not only in Provence, Languedoc and Aquitania, but also in Spain and Italy.

\section{Occitan in Spain}

In Spain, Catalan is very close to Occitan. One isogloss that marks the Occitan/ Catalan region is the names of the days of the week. In French, Italian and Castilian, the words for Tuesday are mardi, martedi and martes (Latin: Martis dies) respectively, whereas Catalan and Occitan have dimars and dimarts (Latin: dies Martis), respectively. The same applies to the other days of the week. ${ }^{5}$

The importance of Occitan in Spain is reflected in the great number of troubadours who were born in or emigrated to Catalonia or Valencia. It is also reflected in the importance of Guiraut Riquer's Supplicatiò, which was directed to Alphonse $x$ the Wise (1221-1284) followed by a Declaratio about the different functions of joglar (performer) and trobador (poet). ${ }^{6}$ In a sense, the Catalans were represented by the Occitan troubadours. Because at the time there were many Catalan settlements in the Mediterranean, it is unsurprising that in his De vulgari eloquentia (I, 8) Dante Alighieri does not mention the Castilian language as the language of the Hispani, but instead mentions Occitan, which played a conspicuous role in Italy because many Occitan troubadours-both

2 Alvira Cabrer, Las Navas de Tolosa, 1212.

3 Alvira Cabrer, El jueves de Muret.

4 The word 'troubadour' [Occitan: trobador] comes from 'find a melody' (trobar), or from tropator (maker of melodic or rhythmic compositions) or from Arabic tarab (music, pleasure) and mutrib 'singer, musician'.

5 In Portuguese, Russian and Arabic, the weekdays are counted: cf. Terça-feira 'Tuesday' (Latin: tertia feria), Cf. Arabic: yawm ath-thalāthā'i.

6 De Riquer, Los trobadores, introducciòn. 
native Italians and immigrants-also lived in Italy. In Italy, the science of philology of the Occitan troubadours started early, as did the conservation of vidas (the lives and biographies of troubadours) and razos (poetry comments).

\section{Occitan in Italy}

In Italy, Occitan was used for poetry: the oldest Occitan poem in Italy was written by an Italian, Pier de la Cavarana, who, probably in the spring of 1194, wrote a sirventes (political satire) to call upon the Italians to take up arms against the German Emperor. ${ }^{7}$ It is remarkable that at such an early date this poem was sent into the world, and in Occitan, not Italian, even though the poem was aimed at Italians and their national feelings. Thus many poets living in Italy wrote their poems in Occitan. Italian as a poetic language came later, but its love poetry was inspired by Occitan love poetry, as first evidenced by the Sicilian school.

\section{Dante's De vulgari eloquentia and Divina commedia on Romance Vernacular Poetry and Prose}

Dante's De vulgari eloquentia is not merely a book about the contrast between vernacular languages and Latin. It is above all a book that is devoted to the Italian situation, with the focus on poetry and the place that Dante's school took therein. Dante knew that he had to be modest and could not mention his name, but he often says in a veiled manner that he is the best poet of the best poetry school, and has the best master from the classical age, namely Virgil. ${ }^{8}$

Poetry and poets also occupy an important place in the Divina Commedia. ${ }^{9}$ In Purgatorio, Dante discusses the place and rank of the poets of his time. He also deals with Occitan poets, for instance Giraut de Borneil and Arnaut Daniel. The latter is called 'the best smith of his mother tongue' and he is introduced speaking Occitan, whereas most of the Divina Commedia is written in Italian. The three vernaculars that are literary languages in Italy are named after the word for 'yes', that is, Oc for Occitan, Oil for French and Si (Latin: sic est) for Italian. Dante presents a kind of contrasto (juridical dispute) in which each of

\footnotetext{
7 Crespo, 'Frans, Provençaals en Italiaans', p. 24.

8 Cf. Dante, De vulgari eloquentia, I, x; Divina Commedia, Inferno 1, 11. 85-87.

9 Cf. Dante, Divina Commedia, Purgatorio 26, $11.91 \mathrm{ff}$.
} 
the three vernaculars defends herself on the basis of her qualities. The Occitan vernacular is the first to speak, and she puts her expansion down to her love poetry. French is mainly known for her historic prose writings or epic writings. In Italy, both Occitan and French were popular literary languages, each in its own domain. There were vulgarizations of historical texts, but also the travels of Marco Polo or the Trésor by Brunetto Latini, who is known as the 'master' of Dante. Furthermore, there were Arthurian romances in French.

Roberto Crespo found it remarkable that in his De vulgari eloquentia Dante does not refer to the Roman de la Rose when talking about French, even though Dante was the author of an Italian adaptation of the Roman de la Rose, entitled Il Fiore, which he wrote entirely in the new strophic form of the sonnet. ${ }^{10}$

\section{Italian Poetry Schools and Love Poetry}

After Occitan and French, Italian comes to the front, and Dante Alighieri is proud of his dolce stil novo ('sweet new style'), a style in love poetry that makes the language 'sweeter' and 'more subtle', because of the clarity of the language, which is closer to Latin than the other two Romance languages, and 'more subtle' because of the philosophic language that is used in poetry to describe love." For instance, in one of his poems, he invokes people who move the sphere of Venus, the third heaven. Dante's poetry was preceded in Tuscany by other schools of love poetry, with poets such as Guittone d'Arezzo and Guido Cavalcanti. Before that there was the Sicilian school (scuola siciliana) in Sicily, influenced by troubadours and trouvères, where Jacopo da Lentini in particular was an important poet. This school was linked with the court of Emperor Frederick II (1194-1250), in the third decade of the 13th century. His grandfather Roger II (1095-1154) had been a patron of Arabic poets. In al-Andalus (Muslim Spain), and also in Sicily, were written early on Arabic love lyrics, for instance by the poet Billanūbī, who sometimes even wrote strophic poetry. In Dante's writings it is evident that he places himself in the tradition of the troubadours, the Sicilian school and the poetry schools of Tuscany. The love themes are important in more than one poetry and literature in Italy and Spain.

Hebrew poets from Spain and Sicily also wrote love poems. In this context, the strophic forms - muwashshahạt and azjāl—are important for both Arabic

10 Crespo, 'Frans, Provençaals en Italiaans', p. 21.

11 See Crespo, 'Frans, Provençaals en Italiaans', Dante, De vulgari eloquentia I, x, Schippers, 'Les troubadours', Schippers, 'Liebesleid'. 
and Hebrew poetry. These strophic genres originated in al-Andalus and then spread to the rest of the Arabic and the Hebrew world. ${ }^{2}$

\section{Strophic Love Poetry in Arabic, Hebrew and Occitan}

The muwashshah ${ }^{13}$ or 'girdle poem' (strophic poetry in classical Arabic) was developed from the eleventh century onwards together with the strophic genre of the zajal in colloquial Arabic. ${ }^{14}$ This colloquial form was a western Arabic dialect, which we call andalusi. We find in the muwashshah, which is normally conceived in classical Arabic, quotations in colloquial Arabic and even quotations in Romance language in the last part of the poem, the kharja ('exit refrain'). Both strophic genres often have bilingual or trilingual characteristics: Romance sentences, classical Arabic, and colloquial Arabic and Hebrew. ${ }^{15}$

As a matter of fact, the description of the wind as a messenger can be combined with the theme of suffering from love as we can see in some strophes of the muwashshah by Ibn Baqī: ${ }^{16}$

o. Ajrat la-nā min diyāri -l-khilli//

rīhu'l-ṣabā 'abarāti -l-dhilli//

o. From the dwelling place of the beloved //

the wind of dawn leads towards us tears of humility//

1. Habbat hubūba -l-ḍanā fì badanī//

wa-hayyajat mā maḍā min shajanī//

tahdī tahiyyata man 'adhdhaba-nī //

jawan 'alā kabidi -l-mu'talli//

lā kāna yawmu -l-nawā fì ḥilli!//

1. Languishing sighs [of the wind of daybreak] penetrate my being //

They revive old anguishes//

They bring greetings towards me from the one who torments me

\footnotetext{
12 Stern, Hispano-Arabic Strophic Poetry; Zwartjes, Love Songs.

13 Corriente, Poesía dialectal árabe y romance en Alandalús.

14 The most important zajal poet was Ibn Quzmān, see Schippers, 'The mujūn Genre'.

15 Schippers, 'Muwaššah', idem, 'Semantic Rhyme (Parallellism)'.

16 Schippers, 'De rol van het Arabisch', Appendix; idem, 'Medieval Languages', pp. 24-25.
} 
With lovesickness in my sick heart//

Oh, may the day of departure be cursed!//

2. Mādhā 'alayya -l-hawā ajnā-hu//

Mudh șadda 'an-nī-l-ladhī ahwā-hu//

Wa-laysa lī fî-l-hawā illā-hu//

Kayf-ștịārī abā 'an wașlī //

Wa-mā-ḥtiyālī 'alay-hi ? Qul-lī.//

2. Why was Love behaving so cruelly with me!//

Since the one I loved turned himself away from me//

And I have only him as a beloved//

How can I bear that he refused to meet me?//

What kind of strategy do I have to follow? Tell me.//

3. Ūbī ‘alay-hi a-rīhu ūbī //

wa-ballighī wațana-l- maḥbūbi//

tahiiyyata-l-āshiqi-l-makrūbi//

wa-qabbilī fì makāni-l-qubli//

'an-nī wa-ḥayyī bi-'arfi-l-dalli//

Go back to him (my beloved), go back oh breeze//

And bring to the homeland of the beloved//

A greeting of a sad lover//

And kiss on the place to be kissed (on the cheek)//

In my name and greet with the perfume of elegance.//

4. Dallin ka-fāḥimi laylin ja‘di//

Qad khața fi șaf̣atin min wardi//

Ka-'ațfati-l-nūni fawqa-l-khaddi//

Aw șawlajin ākifin aw șilli//

ḥamat ḥamā-hu shifāru-l-naṣli//

4. The little hair on the temple black as the coal of night and curled//

Is sketched on a surface consisting of roses//

Like a kind of curve of a letter $\mathrm{N}$ on the cheek//

Or a curved stick or a viper //

Whose cave is defended by the blade of a sword.// 
5. Wa-rubba khawdin jafā-hā-l- wajdu//

Wa-shaffa-hā-l-baynu thumma-l-bu'du//

Fa-a'lanat bi-l-firāqi tashdū: //

«Benid la Pascua, [ed] aun shin elli//

Com Cande meu corajon por elli »//

5. And many a maiden who was vexed by her love passion//

While separation as well as distance from her beloved had made her meagre//

Announced her divorce by singing:

'The appointed time of the tryst has come, but without him//

How burns my heart for him.'//

The strophes cited have some themes and motifs in common with the troubadours' Occitan love poetry. First, there is the theme of the wind as a messenger of the beloved. This can also be found in troubadour poetry. To give some examples by Bernard de Ventadour: ${ }^{17}$

Quan la frej' aüra venta//

Deves vostre païs//

Vejaire m'es que senta//

Un ven de paradis/

per amor de la genta /

vas cui eu sui aclis//

When the fresh air blows/

From your country, /

It appears me that I feel/

A wind coming from paradise,/

Because of my love for the people/

To whom I am attached.//

And by Peire Vidal: ${ }^{18}$

Ab l'alen tir vas me l'aire/ qu'ieu sen venir de Proensa;/ tot quant es de lai m'agensa/;

17 Riquer, Trovadores, I, p. 388.

18 Riquer, Trovadores, II, p. 872. 
When breathing, I inhale the air/

Which I feel coming from Provence;/

Everything that comes from there, makes me happy./

And by an anonymous poet: ${ }^{19}$

Per la douss'aura qu'es venguda de lay/

Del mieu amic belh e cortes e gay,/

Del sieu alen ai begut un dous ray/;

Because of the sweet air that came from there,/

from my beautiful, courteous and gay friend,/

I have got a sweet ray of his breath. /

And by Raimbaut de Vaqueiras: ${ }^{20}$

Oy, aura dulza, qui vens dever lai,/

Un mun amic dorm e sejormn e jai/

del dolz aleyn un beure m'aportay/

La bocha obre, per gran desir qu'en ai/. ${ }^{21}$

O, sweet air, which comes from there, /

where my friend sleeps, sojourns and lies,/

give me a sip from his sweet breath,/

I open my mouth because of the great desire I have for it./

In the second strophe of the above-mentioned muwashshah, the poet/lover complains that Love was cruel to him, which is also a well-known troubadour motif. In the third strophe the sad poet/lover wants, in his turn, the breeze or the wind to take his greetings to his beloved. The fourth strophe presents the physical qualities of the beloved. In troubadour poetry, the physical qualities of the beloved lady are sometimes praised. But here the picture is typically Arabic, with its colour-based metaphors: the hair on the beloved lad's temple is black and curling like the letter $\mathrm{N}$, and the red blushing cheeks are like roses. The poet constructs a fantastic aetiology for the behaviour of the hair: the roses of the lad's cheeks must be prevented from being 'plucked' or

\footnotetext{
19 Riquer, Trovadores, III, p. 1696.

20 Riquer, Trovadores, II, p. 844.

21 Schippers, 'Medieval Languages', pp. 24-25.
} 
'kissed. The role of defending the cheeks is given to the hair, which looks like a viper, or sword or curved stick, whose task it is to defend the 'cave' of roses. A kind of imaginary link is constructed between these hairs and the red cheeks of the lad. Typical of Arabic is also the possibility of a homosexual beloved: the beloved can be a boy or a girl, whereas in Christian poetry only heterosexuality is possible.

\section{The Romance kharja ('Exit Refrain') in Arabic and Hebrew}

In the fifth strophe the sad male beloved is compared with a sad Christian girl whose lover did not come to the appointed place at the appointed time. We know from Hebrew poetry that the girl is often a Christian: there the girl is said to be Edomit (Christian) or to speak edomit (Christian language), ${ }^{22}$ namely a Romance dialect. So the fifth strophe, called kharja ('exit refrain'), often contains a Romance text, apparently a quote from a supposed daily reality in a love affair. The text says: Easter, or 'the time of the appointment', has come, but the supposedly Arabic love partner has not come yet. The same Romance kharja text can also be found in a Hebrew muwashshah ${ }^{23}$ by the poet Yehudah haLewi (1074-1141), who sent his condolences to his fellow poet Moses ibn Ezra (1035-1138) whose brothers had passed away, leaving him feeling lonely and sad like the Christian girl whose lover did not come to the rendezvous: ${ }^{24}$

5. Shir ah meforad be-libbi kidod//

Yashir ke-'almah lebabah yiddod//

Ki mo'adah ba we-lo ba had-dod//

Benid la Pascua ediyawn shin-elu//

Kom cande meu corajon por-elu//

5. The song of the brother who has been left alone scars my heart like fire//

His song is like that of a maiden whose heart flutters//

Because the appointed hour has come, and the beloved has not arrived:// 'The appointed time of the tryst has come, but without him//

How burns my heart for him.'//

22 Stern, Hispano-Arabic Strophic Poetry, pp. 141, 147.

23 Yehudah ha-Levi, Dīwān, ed. Brody, Berlin 1904, I, pp. 168-69 [no. 111].

24 Stern, Hispano-Arabic Strophic Poetry, p. 135. 


\section{Interactions between Arabic, Hebrew and Romance Poetry}

The Arabic and Hebrew muwashshahāt mentioned in the preceding passage suggest a strong interaction between Arabic, Hebrew and Occitan love poetry, especially in Spain. However, we cannot prove it. One of the interactions between the troubadour literature and the secular Hebrew literature of the Arabic tradition ${ }^{25}$ that have actually been proved is a catalogue poem by Abraham Bedershi (second half of the thirteenth century CE) entitled the Turning Sword, ${ }^{26}$ which mentions lots of Hebrew poets from Spain and Provence from the eleventh century CE onwards, as well as two Occitan and two Arabic poets.

Another interaction is the poetic work consisting of the Cantos or Mahbarot by the Italian Hebrew poet Immanuele Romano or Manollo Giudeo (12701328). ${ }^{27}$ Immanuele Romano was inspired by the Arabic tradition that originated in Spain, ${ }^{28}$ and he inserted the Romance poetic form called sonnet into his rhymed prose texts of the Cantos. His rhymed prose narrations were inspired by the Hebrew maqāmāt or mahbarot of Yehudah al-Harīīi, who was born in Spain, travelled to Provence and Egypt, and died as an Arabic poet in Aleppo (Syria) in $1225 \cdot{ }^{29}$

Immanuele was also inspired by his colleague Dante, and some typical 'philosophical' expressions from the dolce stil novo are to be found in his Hebrew work. In his sixth Mahberet or Canto he deals with the same kind of poetic rivalries as Dante in his De vulgari eloquentia and Divina Commedia:Purgatorio, this time between Spanish Hebrew poets, Hebrew poets from Provence, and Hebrew poets from Rome and Italy. His Hebrew poems have metres derived from the Arab classical metres. His Hebrew sonnets are according to quantitative Arabic metres as well as the Romance accentuation of the sonnet. ${ }^{30}$

Moreover, Immanuele was also an Italian poet, belonging to the poeti giocosi (humoristic poets) of the same school as Cecco Angiolieri (1260-1312). In one of his Italian elegies, we find a clear Arabic influence in his use of hyperbolic images.

25 Schippers, 'Les troubadours et la tradition poétique hébraïque', idem., 'Les poètes juifs en Occitanie'.

26 Polak, Chotam tochnit.

27 Yarden, The Cantos.

28 Schippers, Spanish Hebrew Poetry.

29 Schippers, 'Medieval Opinions on the Spanish school'.

30 Schippers, 'Some Questions of Italian Hebrew poetics'. 


\section{Latin and the Vernaculars in Italy}

Speaking about the relationship between Latin and the vernaculars, the best thing to do is look at the local circumstances in Spain and Italy respectively. At first sight, the situation of Latin is linked to the local situation, especially in Italy where the three great Italian writers of the Trecento-Dante, Petrarch and Boccaccio - made important contributions to Latin or did important philological work, such as Boccaccio's 'discovery' of Tacitus. I have already quoted some Latin work by Dante, such as De vulgari eloquentia; also important are De monarchia, which gives his view on the papacy in relation to the Emperor, and his letters (Epistulae). Dante's Latin works are clearly secondary to his poetic works in Italian, but he uses Latin for concepts he could not express otherwise.

Petrarch uses Latin for his main writings, such as his 'letters' (for instance the Seniles) and his epic writings, such as his Africa. He considers his Italian poems nugae ('trifles'), in other words, as not being so important. Boccaccio, with his Decámeron, developed Italian vernacular in prose style. So in Italy, the most important vernacular writers also wrote in Latin. The Italian vernaculars did not develop to an extent sufficient to supplant Latin entirely.

In Italy the dichotomy Latin-Italian is not the whole story, because in the beginning Italian poets mainly used Occitan as a vernacular. For example, Dante occasionally used Occitan in his description of the poet Arnaut Daniel in his Purgatorio. For prose, including epics and 'historiographic' texts, they often used French, as did Dante's 'master', Brunetto Latini.

In the beginning, the use of vernaculars was functional: Occitan for lyrics, and French for prose. Italian started with lyrics, the Scuola siciliana and the various poetry schools of Tuscany; later, it was also used for prose: for storytelling such as Masuccio Salernitano's Novellino, and Boccaccio's Decámeron. And the Italian volgarizzamenti replaced French as the language of 'historiographic' texts.

\section{Latin and the Vernaculars in Spain}

In Spain, there are important Latin texts about language and poetry (the Indiculus Luminosus by Albar, ${ }^{31}$ marking the beginning of Arabic influence on poetry) and religious history (religious debates between Jews, Christians and Muslims), general history (Historia Gothica, Historia Arabum by De Rada) and literature (Disciplina clericalis, 'translated from the Arabic' by Petrus Alphonsi, alias Moshe Sefardi, a Jewish convert to Christianity, who lived from 1062-1121). 
In the thirteenth century CE, Latin acquired a prominent position in science and philosophy, because of the school of translators in Toledo. This ultimately led to the translation of Arabic (and Hebrew) storytelling and scientific works into Castilian during the reign of Alphonse $x$ theWise (1221-1284; Alfonso el Sabio). ${ }^{32}$

In the beginning, Occitan, together with its kindred language Catalan, occupied the most prominent position thanks to the troubadours and the Catalan presence in the Mediterranean. Its position was much stronger than that of Castilian, which is also clear from the fact that Dante, in his De vulgari eloquentia, mentions only Occitan as a language of Spain; he had apparently never heard of Castilian. Due to Alphonse the Wise's translation school, Castilian finally acquired a position. In Spain we cannot speak of a dichotomy between Latin and a particular vernacular, because at the court of Alphonse the Wise, for instance, several vernaculars were used for various purposes: Occitan was used for troubadour poetry by Spanish poets, among them Guiraut Riquer who asked Alphonse to make an official distinction between trobador (poet) and joglar (performer); moreover, Galician Portuguese was also used as a poetic language at his court, namely for his obscene poems and for the Cantigas de Santa María ('Strophic Songs in Honour of Saint Mary'). Galician Portuguese started as a language for love lyrics resembling the troubadour love lyrics. Castilian was mainly used for prose, in the many translations from Arabic as well as in the Siete Partidas ('Law Books') and books about chess and other games. Arabic and Hebrew poetry were also represented at his court by the famous Hebrew poet Todros Abū-'l-'Āfiyah (1247-1296), whose introductory texts and poems were composed in Arabic. Just like in Italy, more than one vernacular was used, and also here there was a distribution of functions or 'task' allocation between poetry and prose and other genres.

\section{Conclusion}

So in Spain and Italy there is no dichotomy between Latin and a single vernacular; multiple vernaculars are involved. There is thus no question of bilingualism; instead, there was multilingualism. To this I have to add that in Spain as well as in Italy there were also two other important cultural languages in which prose and poetry genres were written, namely Arabic and Hebrew, which exercised their influence on love poetry, storytelling and scientific writings. In lyrical Arabic and Hebrew poetry, use was even sometimes made of Arabic and Romance dialects.

32 Schippers; 'Wetenschap vertaald'; Alfonsi, Disciplina clericalis. 


\section{Appendix: Languages and Literatures in Hispania, Italia and Occitania}

\section{HISPANIA nth-Beginning 14th Century}

\section{Languages and Literatures}

LATIN OFFICIAL DOCUMENTS, LITERATU RE: Alvar, author of the Indiculus luminosus; Petrus Alphonsi [= Moshe Sefardi] (d. c. 1140) Disciplina clericalis; science; Rodrigo Jimenez de Rada, archbishop Toledo: 1210-1247, wrote Historia Gothica and Historia Arabum; Hermannus Alemannus of Carinthia: De essentiis; translator Arabic comment Averroes on Aristotle into Latin; Gerard of Cremona (d. 1187), Michael Scot (in 1217 in Toledo); Daniel van Morley, Liber de naturis inferiorum et superiorum (between 1175 and 1187); Ramon de Llull (1252-1315).

CATALAN James the Conqueror, Catalonia (-1276), Llibre dels Leyts; Ramon de Llull (1252-1315).

CASTILIAN Alphonse $\mathrm{x}$ the Wise (1221-1284) Siete partidas, Libro de los Juegos de Ajedrez, Dadosy Tablas.

GALICIAN-PORTUGUESE Alphonse $x$ the Wise (1221-1284) cantigas de Santa Maria; some obscene poems; in Portugal: cantigas de amigo; cantigas de amor; Cancioneiro da Ajuda.

OCCITAN troubadours WORKING OR COMING From SPAIN: Raimon de Miraval (..1190-1220 ...); Peire Vidal (..1183-1204...); Marcabru (..1130-1149 ...); Peire d'Alvernha (..1149-1168 ...); Folquet de Lunel (..1244-1284 ...); Giraut de Bornelh (..1162-1199 ...); Huguet de Mataplana (...1185-1213...); Guiraut Riquier

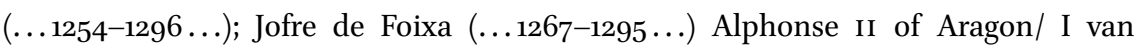
Barcelona (1154-1196); Pong de la Guardia (..1154-1188...); Guillem de Bergueda (...1138-1192 ...). Other poets: Ramon de Llull (1252-1315).

ARABICPOETRY AND SCIENTIFIC LITERATURE:Abū-l-Walīdal-Himyari (418/1026440/1048); Ibn Zaydūn (394/1003-463/1071); Wallāda bint Muhammad al-Mustakfí (d. 484/1091); Ibn Shuhayd (382/992 426/ 103 5); Ibn 'Ammar (422/1031-476/1084); al-Mu'tamid (1040-1095); Ibn Khafāja (533/1058-533/1139), Ash-Shaqundi (d. 629/1231); Ibn az-Zaqqāq (489/1096-528/1134); Ibn Bassām (d. 543/1148); Ibn Sahl (d. 649/1251); Ibn Zamrak (1333-1398); Ḥaf̣̦ah bint al-Ḥajj al-Rakūniyya (12th c.); al-Rușāi (d. 1177); Ibn al-'Arabi (1076-1148); Ibn Sahl (13th c.); Ibn Rushd, Ibn Ṭufayl, Ibn Bājjah (12th c.); Abraham ibn Da'ud (12th c.); Moses ibn Ezra (1055-1138), Ramon de Llull (1252-1315).

HEBREW PоEтRY: Shelomoh Ibn Gabirol (1021-1055); Moses ibn Ezra (1055=1138); Yehudah hal-Lewi (1075-1141);Samuel ha-Nagid (993-1056); Todros Abū'l-'Āfiyah (12471298 ...); stories in rhymed prose: Yosef Ibn Zabbārah (b.1140); Yehudah ibn Shabbetay (1168-1225...); Yaaqov ben El'azar (end 12th-begin. 13th c.); Meshullam da Piers (first half 13th c. $-1260 \ldots$...); Shem Tob ben Yosef Falaquera (1225-1290 ...); Yishaq ben Shelomoh Ibn Sahulah (1244-1281 ...); science and religion: Abraham ibn Da’ud (12th c.). 


\section{ITALIA 12th, 13th and Beginning 14th Century}

\section{Languages and Literatures}

LATIN official Documents, treatises, LetTers, epic Works: Dante, Petrarch, Africa, and Boccaccio; science: Thomas of Aquino; Constantine of Africa; HISTORIOGRAPHY, DIDACTIC POETRY; teatro sacro.

FRENCH POPULAR HISTORICAL AND DIDACTIC WRITINGS: Brunetto Latini, Trésor (1260-1266); Martino da Canal, Les estoires de Venise; (1267-1275); Rustichello da Pisa, Livres des merveilles de l'Inde; Marco Polo (ca. 1298).

OCCITAN trou badours IN ITALY: Frederico II I di Sicilia (1272-1337); Bartolomeo Zorzi (1266-1273); Alberto Malaspina di Lunigiana (b. second half 11th c.); Lanfranco Cigala (1235-1257); Bonifacio Calvo (1253-1266); Rambertino Buvallelli; Sordello di Goito (1220-1269); Paolo Lanfranchi; Pier de la Caravana di Pistoia (1282-1295); Perseval Doria (1228-1264); important occitan troubadours in Italy: Peire Vidal, Raimbaut de Vaqueiras and Aimeric the Peguilhan.

ITALIAN DIALECTS poets of Sicilian school: Pier de la Vigna; Jacopo da Lentini, Guido delle Colonne, Rinaldo d'Aquino, Stefano Protonotaro da Messina, Giacomino Pugliese; poesia contese: Guittone d'Arezzo, Buonagiunta Orbicciani, Chiaro Davanzati; Dante da Maiano; Dolce stil nuovo: Guido Guinizelli, Guido Cavalcanti, Lapo Gianni, Gianni Alfani, Dino Frescobaldi, Cino da Pistoia; Poesia giocosa, comica realistica: Rustico Filippi, Cecco Angiolieri, Manollo Giudeo [=Immanuele da Roma]; Federico II (1194-1258); Dante, Petrarch, Boccaccio.

ARABIC ON SICILY: POETRY: Ibn al-Qaț̣̄āc (1oth c.), Ibn al-Khayyāṭ (late 1oth/early 11th c.), Ibn Hamdīs (1056-1133), 'Ali al-Ballanūbi; 'Abd al-Raḥman ibn Abī al-'Abbās al-Kātib, known as al-Ațrābanishi (i.e. from Trapani); scıence: Abū Hafṣ 'Umar ibn Hasan; Ibn Sabīin.

HEBREW POETRY AND PROSE: Abraham ibn Ezra (1092-1167); Immanuele da Roma (1261-1332); Sicily: poet Anatoli ben Joseph (1150-1215); SCIENCE AND HISTORY: Abraham ibn Ezra, Yehudah ben Shlomoh ha-Kohen Ibn Mitqah.

\section{OCCITANIA 12th, 13th and Beginning of 14th Century}

Languages and Literatures

LATIN Andreas Cappellanus 'De Amore' [around 1185]; Petrarch; etc.

OCCITAN poetry: Alfonso of Aragon; Richard Cor de Leo; Guilhem d'Aquitania; Martín Codax; Azalais de Porcairagues; Bertran de Born; Beatriz de Dia; Folquet de Marselha; Jaufré Rudel; Raimbaut de Vaqueyras; Guillem Ademar; Peire d'Alvernha; Monge de Montaudon; Peirol (Hugues de Peirols); Raimon Vidal de Bezaudun (ou Provençal); Uc la Tor; Guilhem de Ventadorn; Peire Cardenal. 
HEBREW POETRY AND PROSE: Yehudah al-Harāzī (1160-1225); Abraham Bedershi; Yishạa bar Yehudah bar Nethaniel ha-Seniri (1170-1230); David de Lunel (Yerahi); Aryeh Yehudah of Montpellier; Yehosha; Melguieri; Yedaiah ben Abraham Bedarshi ha-Penini [En Bonet] (ca. 1270-1340); Abraham ibn Ezra (1092-1167); Yehudah ibn Tibbon (1120-1190); Samuel ibn Tibbon (ca. 1235); Joseph Qimhi (1105-1170); David Qimḥi (116o-1235); Mosheh Qimḥi (d. 1190); Profiat Duran (d. ca. 1414). 